\title{
Article \\ Social and Environmental Assessment of a Solidarity Oriented Energy Community: A Case-Study in San Giovanni a Teduccio, Napoli (IT)
}

\author{
Serena Kaiser ${ }^{1}$, Mariana Oliveira ${ }^{1, *}$, Chiara Vassillo ${ }^{2}$, Giuseppe Orlandini ${ }^{3}{ }^{\mathbb{C}}$ and Amalia Zucaro ${ }^{4}$ \\ 1 International PhD Programme, UNESCO Chair "Environment, Resources and Sustainable Development", \\ Department of Science and Technology, Parthenope University of Naples, Centro Direzionale, Isola C4, \\ 80143 Naples, Italy; serena.kaiser001@studenti.uniparthenope.it \\ 2 Department of Agriculture, University of Naples Federico II, 80138 Naples, Italy; cvassillo@gmail.com \\ 3 Independent Researcher, 80137 Naples, Italy; orlandinigiuseppe@yahoo.it \\ 4 ENEA, Department for Sustainability, Resource Efficiency Division, Research Centre of Portici, \\ 80055 Portici, Italy; amalia.zucaro@enea.it \\ * Correspondence: mariana.oliveira@studenti.uniparthenope.it
}

Citation: Kaiser, S.; Oliveira, M.; Vassillo, C.; Orlandini, G.; Zucaro, A. Social and Environmental Assessment of a Solidarity Oriented Energy Community: A Case-Study in San Giovanni a Teduccio, Napoli (IT) Energies 2022, 15, 1557. https:// doi.org/10.3390/en15041557

Academic Editor: Martin Junginger

Received: 24 December 2021

Accepted: 15 February 2022

Published: 20 February 2022

Publisher's Note: MDPI stays neutral with regard to jurisdictional claims in published maps and institutional affiliations.

Copyright: (C) 2022 by the authors. Licensee MDPI, Basel, Switzerland. This article is an open access article distributed under the terms and conditions of the Creative Commons Attribution (CC BY) license (https:// creativecommons.org/licenses/by/ $4.0 /)$.

\begin{abstract}
Renewable energy communities (RECs) are alternatives toward sustainable production and consumption pathways. In 2020, Italy implemented the EU Directive 2018/2001, defining a common framework for promoting energy from renewable sources. The "Famiglia di Maria", a foundation dealing with social issues in San Giovanni a Teduccio, Napoli (Italy), in collaboration with "Legambiente" and "Con il Sud" Foundations, released the first Solidarity Oriented Renewable Energy Community project in Italy. Therefore, by applying social life cycle assessment (s-LCA) and life cycle assessment (LCA) methodologies, this study aims to: (i) promote the dissemination of RECs in the Italian and European contexts, (ii) suggest REC scenarios for the best social and environmental solutions, and (iii) support the policymakers for sustainable local development. Some key results show that the solidarity-oriented project has already produced mature outcomes about community cohesion. In contrast, technical skills and awareness about environmental issues still need to be further developed and shared among the stakeholders. Finally, social and environmental indicators converge on the self-consumption model as a feasible alternative for energy justice, community empowerment, and economic and market competition independence.
\end{abstract}

Keywords: s-LCA; LCA; energy communities; empowerment; energy justice

\section{Introduction}

Centralised services have shown their weakness, especially during the COVID-19 pandemic. For instance, the hospital-based health system has stalled because of too much concentration of services demand, most often causing inadequacy of territorial assistance $[1,2]$. Therefore, the reorganisation of centralised services, including energy production, needs to be addressed. The interest for "reterritorialisation" based on sustainable energy production, small scale self-production, and renewable sources is growing [3]. Several countries are designing future energy plans, including balancing centralised facilities and distributed energy systems [4]. In this context, the new concept of "prosumers" arises. According to Lang et al. [5], prosumers are "individuals who consume and produce value, either for self-consumption or consumption by others and can receive implicit or explicit incentives from organisations involved in the exchange".

Energy Communities (ECs) are becoming a compelling opportunity among the solutions currently proposed to overcome energy production (electricity, heat, and gas) from fossil fuels. ECs promote renewable sources in local territories and decentralised energy production. ECs represent a socio-economic alternative in which the collective dimension 
becomes prominent, thus creating options for social change beyond, and in addition to, environmental protection. Moreover, ECs can be adopted as a solid antidote to energy poverty, aiming to enhance citizens' participation and control over centralised decisionmaking, creating opportunities for empowerment and energy justice [6,7]. Finally, ECs are naturally one of the most virtuous solutions for the energy transition in Europe [8].

Different authors have thoroughly investigated the energy subject from a sociopolitical perspective. A review discloses the concepts of energy democracy, relations between energy and political power, and possible scenarios for the democratisation of renewable energy development [9]. This study offers a comprehensive critical outlook on building community-based renewable energy, assuming that renewables represent a possibility, but not a certainty, to a democratic energy future [9]. In a smart community in the UK, Burchell et al. [10] provide a specific investigation about energy-saving. Through interviews with the participants, the authors discuss the concept of community and the importance of non-commercial projects. Another case study [11] focuses on innovation factors and hybridisation phenomena in a French initiative, highlighting the importance of a new shared identity based on energy projects as a source of new job opportunities and economic wealth and the possibility of reshaping territories from below (from the citizens perspective). Creamer et al. [12] provide a review from a spatial and geographical perspective to express the importance of intermediary organisations, which can play a fundamental role among the State, private organisations, and communities. Bomberg and McEwen [13] analyse mobilising factors preceding the creation of community energy groups by a qualitative study on 100 Scottish groups, explaining community actions motivated by many immaterial and symbolic resources. An Italian review gives energy socio-political and community-oriented perspective [14]. From a markedly political standpoint, a materialistic historical point of view, provided by a Marxist critical thinking, inspires alternatives to the capitalistic model and the fossil-based energy production [15]. Finally, some other studies about blockchain technology formulate suggestions for communities to manage economic transactions without intermediaries, thus providing options for broader autonomy [16].

It would be impossible to sufficiently understand ECs without considering the legal framework for their implementation. Moreover, different political backgrounds provide additional opportunities and affect the operation of ECs in specific territories. In this context, both European and Italian legal frameworks should be considered. The first one would be unworkable without national implementation.

The EU framework is based on the EU Directive 2001/2018, "On the promotion of the use of energy from renewable sources" [17] and Directive 944/2019 "On common rules for the internal market for electricity and amending Directive 2012/27/EU" [18]. Both directives are part of the "Clean Energy Package" (CEP) [19] and define Energy Communities as a juridical subject based on open and voluntary participation, whose priority is not financial profit but environmental, economic, and social benefits for members and territories. In detail, the EU Directive 2001/2018 [17] deals with adequately incentivised administrative frameworks to stimulate the transition from fossil fuels to renewables and defines the Renewable Energy Communities (RECs), whereas the Directive 944/2019 [18] specifies the Energy Communities of Citizens (ECCs). The main differences between the RECs and ECCs are the energy management and the location of power generation facilities. RECs manage electricity, gas, and heat, and the members need to be close to the power production plants, whereas ECCs work exclusively for electricity production without any specific requirements regarding the proximity between the consumers and the power generating facilities $[17,18]$.

The legal context implements the EU Directives in Italy and draws the Italian operative framework. The first regulation about ECs is the Decree-Law 162/2019, so-called "Milleproroghe Decree" [20], which was converted into the Law 8/2020 [21], establishing many opportunities for the promotion of renewable sources of energy. These regulations allow the installation of: (i) power generation plants on private houses to produce energy for self-consumption [20,21]; (ii) collective power generation plants, also managed by a 
third party, to produce energy for groups of people living in the same building $[20,21]$; and (iii) power generation plants for people not living in the same building (including RECs and ECCs), in which direct self-consumption is not allowed. Thus, in the last case, the produced energy must be sold to the local grid and managed by an external service company [19-21].

In 2019, the first ECC was implemented in Bologna (Italy) [19], but the first Solidarity Oriented REC was launched in October 2021, in Southern Italy (San Giovanni a Teduccio, Napoli). The Solidarity Oriented REC has as the primary beneficiary the group of families living in the neighbourhood that will be monetarily rewarded from the electricity produced by the photovoltaic panels installed on the rooftop of a local building.

In this work, to evaluate the social and environmental sustainability of the Solidarity Oriented REC of San Giovanni a Teduccio, the life cycle assessment methods (s-LCA and LCA for social and environmental evaluation, respectively) were applied to: (i) promote the dissemination of RECs in the Italian and European contexts, (ii) suggest REC scenarios for the best social and environmental options, and (iii) support the policymakers for sustainable local development.

\section{Materials and Methods}

\subsection{The System-Territorial Context}

The Solidarity Oriented REC is located in San Giovanni a Teduccio, VI district of the municipality of Napoli (Southern Italy). This territory has a historical environmental and social exploitation background since industrialisation occurred during the 1950s. Companies settled in the area (primarily food industries and refineries) instead of creating local economic wealth (except for some job opportunities), destroyed the natural capital of the territory, polluting both the land and the sea [22]. As it often happens, areas with environmental exploitation are also socially and economically depressed [23].

An overview of the social profile of the San Giovanni a Teduccio district is shown in Table 1 and Figure 1.

Table 1. The unemployment rate in VI District and Napoli *.

\begin{tabular}{ccc}
\hline Indicator & Napoli & VI District \\
\hline Unemployment rate, age 20-24 & $69 \%$ & $69 \%$ \\
Unemployment rate, age 25-29 & $47 \%$ & $52 \%$ \\
Unemployment rate, age 30-34 & $34 \%$ & $41 \%$ \\
Unemployment rate, age 35-39 & $26 \%$ & $34 \%$ \\
Unemployment rate, age 40-44 & $21 \%$ & $28 \%$ \\
Unemployment rate, age 45-49 & $15 \%$ & $20 \%$ \\
Unemployment rate, age 50-54 & $11 \%$ & $16 \%$ \\
Unemployment rate, age 55-59 & $12 \%$ & $16 \%$ \\
Unemployment rate, age 60-64 & $10 \%$ & $17 \%$ \\
Unemployment rate, age from 65 on & $10 \%$ & $23 \%$ \\
Inactivity rate & $57 \%$ & $62 \%$ \\
University graduates looking for a job for every & $7 \%$ & $3 \%$ \\
100 inhabitants looking for a job, age 15-34 & & $52 \%$ \\
Middle school graduates looking for a job, for & $46 \%$ & \\
every 100 inhabitants looking for a job, age 15-34 & & \\
\hline
\end{tabular}

* Data come from a 2001 census [24]. 


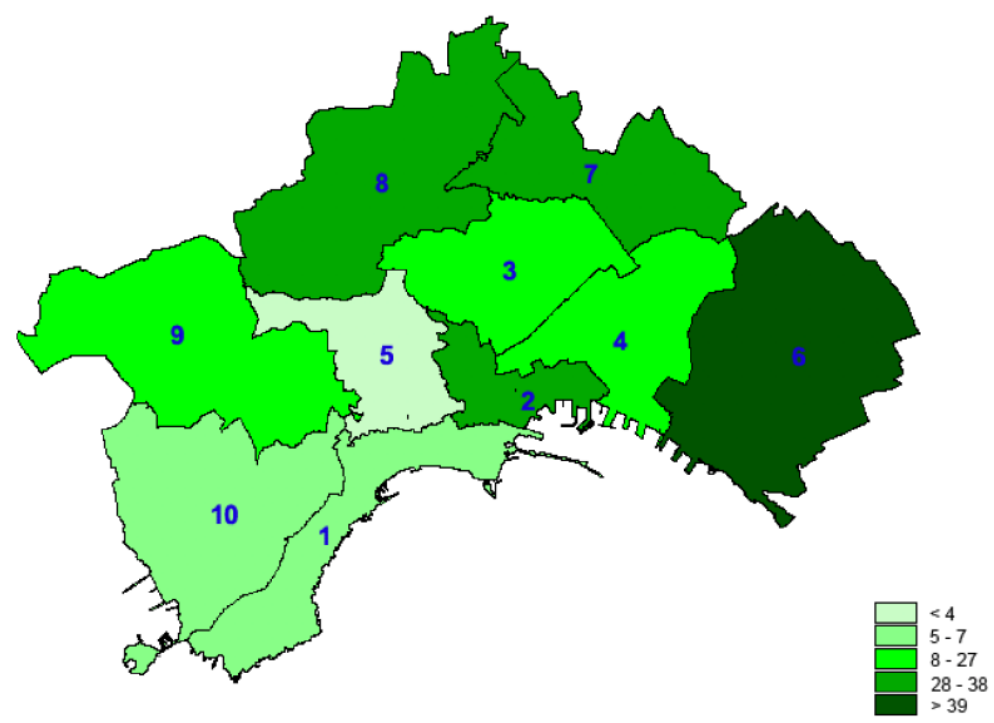

Figure 1. Number of babies born from mothers younger than 20 years old in each district of Napoli in 2008. Numbers on the figure are related to the numerical denominations of districts, whereas different colours refer to the different numbers of children born [24].

The unemployment rates and the education indicators (Table 1) show the social unrest that has led to increasing delinquency in this territory over the years. Figure 1 shows the number of children born from mothers younger than 20 years old, highlighting for the VI district the highest value in the city of Napoli (more than 39 children born from mothers more youthful than 20 years old in 2008). In addition, some other indicators complete the social overview. In $2012,25.7 \%$ of minors (age $0-18$ ) were in foster care, $23.2 \%$ of minors (age 3-18) were in day-care centres, $17.7 \%$ of minors (age 8-16) were in special territorial educational programmes, and $16.3 \%$ of adults were in external penal execution offices [24].

\subsection{The Solidarity Oriented REC Project and Stakeholders}

The Solidarity Oriented REC of San Giovanni a Teduccio is hosted and implemented by the "Famiglia di Maria" Foundation, based on a project developed by the environmentalist association "Legambiente Campania" and funded by the "Con il Sud" Foundation. On the rooftop of the "Famiglia di Maria" Foundation building, photovoltaic (PV) panels were installed to produce electricity to be sold to the Italian electricity grid, providing an income to the beneficiaries (families). The original project involves 40 families connected to the same street power pack and energy box junction (these aspects explain the technical limitation). However, the project faced bureaucratic obstacles from the city administration and started with only 15 families. Because the other families ( 25 families) are expected to be included soon, LCA analysis was applied in this study considering 40 families of the original project. However, a preliminary s-LCA has identified all relevant stakeholders, interviewing seven representatives of these 15 families (face-to-face interviews), the technical partner, and the foundations involved.

The identification of stakeholders is based on several variables, such as liability, influence, proximity, and representation [25-27], to create an easy interaction and encourage communication and comprehension among them [25]. Therefore, all identified stakeholders are:

1. Families;

2. Local community;

3. "Famiglia di Maria" Foundation;

4. "Con il Sud" Foundation;

5. Environmentalist association "Legambiente";

6. Private technical partner: "3eee" Company;

7. Public institutions (national);

8. Public institutions (local). 
The families represent the main stakeholder. Due to current regulation restrictions, they produce and sell renewable electricity. However, when the Italian ECs legislation becomes less obstructive, they might produce and self-consume the generated electricity, selling the surplus to the grid, thus becoming prosumers in the literal sense. In addition, families in this project are also part of the local community, including other local inhabitants out of the Solidarity Oriented REC. The "Famiglia di Maria" Foundation is a local organisation that addresses many social problems in the neighbourhood. They work with children and women, developing projects against school abandonment and gender violence, among other issues. The Foundation physically hosts the PV panels on the rooftop of its building and plays as an intermediary among all stakeholders. The "Con il Sud" Foundation is the leading financial partner of this REC and entirely funded the project. It is a private non-profit organisation founded in 2006 from the alliance between bank-owned foundations and other non-profit organisations. The primary purpose of this Foundation is the development of social and environmental projects to promote social infrastructure in Southern Italy. The environmentalist association Legambiente was founded in 1980, aiming to develop projects in defence of the environment on a solid scientific basis, thus indicating realistic and feasible solutions. The "3eee" Company is the technical partner of the project that installed the PV panels on the "Famiglia di Maria" Foundation building, which manages the bureaucratic and the accounting aspects between the families and the electricity company. Public institutions were identified as representatives of the national and local legal authorities.

\subsection{Assessment Methods}

According to the life cycle thinking tools, social and environmental impact assessments were applied to Solidarity Oriented REC of San Giovanni a Teduccio using social life cycle assessment (s-LCA) and life cycle assessment (LCA). The s-LCA and LCA stages are: goal and scope definition, life cycle inventory (LCI), life cycle impact assessment (LCIA), and interpretation of results [28,29]. For both analyses, a cradle-to-gate approach was used. Thus, the selected system boundary (Figure 2) accounts for the physical limits of the investigated REC, including the installation and maintenance of the PV panels and the electricity production and supply to the national grid. The product of the investigated system is the solar electricity produced and sold to the national grid (following the Italian regulations in which direct self-consumption is not allowed [19-21]).

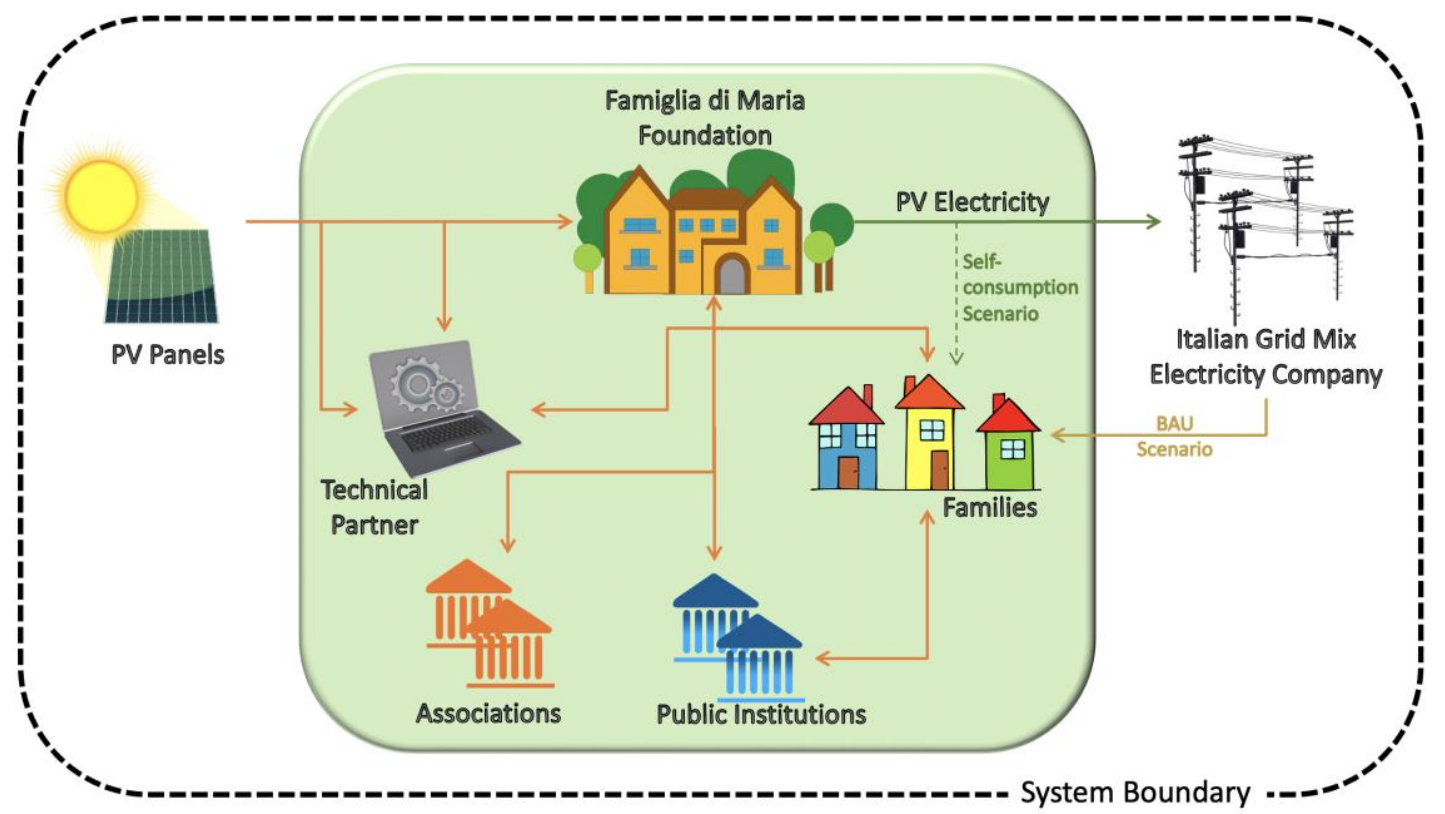

Figure 2. The system boundary of the investigated Solidarity Oriented REC of San Giovanni a Teduccio. 
In this study, the s-LCA was performed to provide a preliminary overview of the social impact generated by the REC. Moreover, the LCA was conducted to outline possible environmental benefits thanks to implementing a social-oriented project in a degraded territory.

\subsubsection{Social Life Cycle Assessment (s-LCA)}

Social life cycle assessment (s-LCA) accounts for social impacts of products and services, highlighting positive and negative impacts, named "opportunities" and "risks", respectively [30]. In this study, the goal and scope of the s-LCA are based on identifying the social impacts of the Solidarity Oriented REC, suggesting good practices for policymakers within the energy transition framework (both from the point of view of energy production and socio-cultural activities). However, considering the social impact from a comprehensive perspective, the definition of a functional unit (FU) can be controversial. Indeed, including only those social impacts from the production of a single product or service can create a "distraction" from the general behaviour of companies: they might perform a specific output in a virtuous way while having a harmful impact within other productive activities [31]. Therefore, in this study, the FU for s-LCA was not considered to provide a broader overview of the social behaviour of the investigated system.

The s-LCA inventory is based on implementing appropriate questionnaires [32] for each stakeholder, completed during face-to-face interviews or remotely. These questionnaires were built based on the selected social indicators identified according to each stakeholder's group characteristics. For the representatives of families, several field visits and live meetings took place to construct and finalise the questionnaire, which was submitted to the families in Italian to break down the language barriers (English translation is provided in Appendix A). For the other stakeholders, face-to-face and remote meetings were both held (Appendix B). Translating the information gathered during this phase into scientific data was challenging and time-demanding due to the enormous amount of collected information (written notes, online forms, and audio recordings). Undeniably, site-specific data (primary data) are more accurate than secondary ones. Still, the interactions between researchers and interviewees, as in any human relationship, might influence the answers, thus negatively affecting the data accuracy [33].

The s-LCI is directly connected to the impact assessment stage. Stakeholders are grouped into different stakeholders categories assessed according to specific impact categories and subcategories [30,34]. Impact categories are related to human rights, working conditions, health and safety, cultural heritage, governance, and socio-economic repercussions. Impact subcategories represent the analytic topic ramifications of the six impact categories for each stakeholder category. In this study, the stakeholders' categories, impact subcategories, and indicator definitions were based on the energy justice-oriented modified version [32]. In Table 2, the stakeholders' categories and related impact subcategories connected to the Solidarity Oriented case study are reported. Impact subcategories indicators are in the results table (Appendix C-based on [32]).

The assessment stage of s-LCA requires the identification of different stakeholders' categories: families are categorised as "Prosumers", merging the concept of producer and consumer, and are also part of the "Local Community". In addition, the "Workers" category is relevant for the foundations and the technical partner, whereas the "Society" category is relevant for all the actors.

In the last stage of s-LCA, the answers to all questionnaires were used to create a preliminary table of results (Appendix C), including numerical values and descriptive sentences. In this study, only some descriptive results were converted into a scale value, whereas others were considered not convertible into numbers $[35,36]$. The qualitative data converted to numerical scale values express the proportion and the level of occurrence of some impacts, based on the answers to the questionnaires. 
Table 2. Stakeholders categories and impact subcategories of Solidarity Oriented REC (adapted from [32]).

\begin{tabular}{|c|c|}
\hline Stakeholders Categories & Impact Subcategories \\
\hline Prosumers & $\begin{array}{c}\text { Freedom of choice about sources } \\
\text { Feedback mechanisms } \\
\text { Costs } \\
\text { Quality of the service }\end{array}$ \\
\hline $\begin{array}{c}\text { Local } \\
\text { Community }\end{array}$ & $\begin{array}{c}\text { Delocalisation and migration } \\
\text { Community engagement and participation } \\
\text { Sense of place and cultural heritage } \\
\text { Respect for local culture } \\
\text { Access to material resources } \\
\text { Access to immaterial resources and information } \\
\text { protests }\end{array}$ \\
\hline Workers & $\begin{array}{c}\text { Child labour } \\
\text { Unpaid labour } \\
\text { Wage } \\
\text { Discrimination } \\
\text { Health services } \\
\text { Safety } \\
\text { Right to unionise } \\
\text { Hours of work and time off } \\
\text { Freedom of mobility } \\
\text { Technology, R\&D } \\
\text { Ethical principles }\end{array}$ \\
\hline Society & $\begin{array}{c}\text { Public commitment to sustainability issues } \\
\text { Prevention and mitigation of conflicts } \\
\text { Contribution to economic development } \\
\text { corruption } \\
\text { Technology development }\end{array}$ \\
\hline
\end{tabular}

\subsubsection{Environmental Life Cycle Assessment-LCA}

Environmental life cycle assessment (LCA) addresses the environmental impacts of a product or a process from a life cycle perspective, evaluating released emissions and resource extractions into different environmental impact categories. This evaluation technique can improve the environmental performance of manufactured and consumed products by identifying bottlenecks (hotspots) and suggesting possible recommendations to improve the environmental performance. LCA accounts for resources from raw material acquisition through production, use, end-of-life treatment, recycling, and final disposal, throughout a product's life cycle and the environmental consequences of releases, using a "cradle-to-grave" approach. However, with proper justification, the LCA technique can also be used in studies with a "cradle-to-gate" or "gate-to-gate" perspective.

The goal to be reached by LCA in this study is to evaluate the potential environmental benefits of the investigated Solidarity Oriented REC of San Giovanni a Teduccio (cradleto-gate approach). Therefore, a comparison was carried out between $1 \mathrm{kWh}$ of electricity produced (selected functional unit) by PV panels and $1 \mathrm{kWh}$ of electricity produced by the Italian Electricity Mix. Moreover, considering a timeframe of 1 year, scenarios were evaluated to provide feasible alternatives aiming to improve the investigated Solidarity Oriented REC. The first investigated scenario considers that the solar electricity produced by the REC is entirely sold to the grid (business as usual scenario-BAU). The second scenario is the self-consumption scenario, in which families consume the solar electricity produced by the investigated REC, and only the surplus is sold to the grid (families as prosumers).

The professional software SimaPro v.9.0.0.48 (Pre-Consultants) coupled with the ReCiPe2016 method [37] and the EcoInvent v.3.5 [38] database were used to set up the LCA model of the investigated system and implement the impact assessment calculations. 
The PV plant of the energy community is composed of 166 PV panels, flat installed on the rooftop of the building belonging to the "Famiglia di Maria" Foundation (primary data collected in the inventory stage). Each PV panel has a power of $330 \mathrm{w}$, totalling $54.78 \mathrm{~kW}$ of installed power [39], produced with 60 cells of $158.75 \mathrm{~mm}^{2}$ made of monocrystalline silicon PV panels; the front has a $3.2 \mathrm{~mm}$ solar glass, and the back has a polymer sheet supported by a frame of aluminium [40]. PV panels are modules with a limited lifetime (the expected lifetime of a PV panel is 25 years). Currently, PV waste is exponentially growing due to the PV expansion market in the last 20 years [41]. However, end-of-life panels treatment options have advantages and disadvantages from the economic and environmental points of view [42].

The LCA was applied to evaluate the avoided environmental impacts of the electricity produced by PV panels installed at "Famiglia di Maria" Foundation, showing and discussing (interpretation of results phase) the environmental and the additional benefits achieved in the families (social) perspective.

\section{Results and Discussion}

\subsection{Social Life Cycle Assessment (s-LCA)}

The starting point of the s-LCA was the identification of stakeholders: families/prosumers, local community, "Famiglia di Maria" Foundation, "Con il Sud" Foundation, environmentalist association "Legambiente", private technical partner "3eee" Company, and public national and local institutions. First, identified stakeholders were grouped and categorised to provide a preliminary overview of the social impacts generated by the evaluated Solidarity Oriented REC of San Giovanni a Teduccio. Next, based on the field visits and live meetings, specific questionnaires for each stakeholder were finalised (see Appendices A and B for additional details).

The answers gathered from the questionnaires' compilation during the interviews provided the results of the implemented s-LCA indicators (Appendix C), summarised in Table 3. These indicators followed the goal and scope definition of the analysis and were selected according to the identified stakeholders' groups. The desired direction of indicators expresses the expected answer (positive or negative; Yes or No) to detect the social impact in terms of risks and opportunities [35].

\subsubsection{Families (Prosumers)}

The answers collected among the representatives of the families provided information about the territory identity and inhabitants relationship with the neighbourhood. In situations in which researchers are not aware of personal and internal dynamics among individuals, the neutral definition of "household" is recommended. However, after the meetings, interviews, and shared social moments, the gained closeness between researchers and the interviewees allows the authors to use the word "families".

The results from s-LCA show, among the most representative indicators for families (prosumers-stakeholder category), the sense of place and the cultural heritage. Therefore, the question "What is a community for you?" highlights the influence of the project on the families' perception. To this question, five respondents answered "A group of people who take part to the collective wellbeing of their own territory"; two respondents answered "A group of people who join to improve their own and theirs living conditions"; no one answered choosing the third possible option, "A group of people that join together to get a goal" (Appendix A). These answers underlined that the Solidarity Oriented REC produces a vast sense of community related to the improvement of wellbeing and is not limited to specific purposes (e.g., energy production or economic gain). The answers to the question "To what extent does receiving a sum of money at the end of the year influence your decision to join the Energy Community project?" shows that the economic benefits provided by the project represent only a tiny part of the positive impacts of the REC. The neighbourhood's problematic social conditions (high level of energy poverty) encourage ambitious projects that offer economic benefits and cultural and social empowerment. 
Furthermore, the empowering processes also need immaterial resources to grow, e.g., social cohesion, awareness, and technical competencies for governance on processes.

Table 3. Selected s-LCA indicators group for Solidarity Oriented REC of San Giovanni a Teduccio.

\begin{tabular}{|c|c|c|c|}
\hline Stakeholders Categories & Indicators Group & Indicators Type & $\begin{array}{c}\text { Desired } \\
\text { Direction }\end{array}$ \\
\hline \multirow{8}{*}{ Prosumers } & \multirow{8}{*}{$\begin{array}{c}\text { Access to information about energy use and sources } \\
\text { of electricity } \\
\text { Choices in electricity generation options } \\
\text { Feedback mechanisms to electricity suppliers } \\
\text { Responses and actions after feedback and complaints } \\
\text { Economic rewarding system } \\
\text { Inequality of electricity costs } \\
\text { Quality of supplier services (burnouts) } \\
\text { Penalties and charges related to the } \\
\text { project membership }\end{array}$} & Semi-quantitative (Yes/No) & Yes \\
\hline & & Semi-quantitative (Yes/No) & Yes \\
\hline & & Semi-quantitative (Yes/No) & Yes \\
\hline & & Semi-quantitative (Yes/No) & Yes \\
\hline & & Semi-quantitative (Scale 1 to 5 ) & Positive \\
\hline & & Semi-quantitative (Yes/No) & No \\
\hline & & Semi-quantitative (Yes/No) & No \\
\hline & & Semi-quantitative (Yes/No) & No \\
\hline \multirow{12}{*}{$\begin{array}{l}\text { Local } \\
\text { Community }\end{array}$} & \multirow{12}{*}{$\begin{array}{c}\text { Involvement and recognition } \\
\text { Participation } \\
\text { Displacement by population group } \\
\text { Involuntary relocation } \\
\text { Land and resources ownership } \\
\text { Resources and electricity access } \\
\text { cultural heritage } \\
\text { Project activities influence the sense of place and } \\
\text { Project activities influence health and safety } \\
\text { Availability of project information } \\
\text { Access to project information } \\
\text { Project policies for local culture preservation } \\
\text { and promotion } \\
\text { Social mobilisation and organisation (protests) }\end{array}$} & Semi-quantitative (Scale 1 to 5 ) & Positive \\
\hline & & Quantitative & Positive \\
\hline & & Semi-quantitative (Yes/No) & No \\
\hline & & Semi-quantitative (Scale 1 to 5 ) & Negative \\
\hline & & Quantitative & Positive \\
\hline & & Semi-quantitative (Yes/No) & Yes \\
\hline & & Semi-quantitative (Scale 1 to 5 ) & Positive \\
\hline & & Semi-qualitative (Poor/High) & High \\
\hline & & Semi-quantitative (Yes/No) & Yes \\
\hline & & Semi-quantitative (Yes/No) & Yes \\
\hline & & Semi-quantitative (Yes/No) & Yes \\
\hline & & Quantitative & Negative \\
\hline \multirow{20}{*}{ Workers } & \multirow{20}{*}{$\begin{array}{c}\text { Child labour } \\
\text { Unpaid labour } \\
\text { Paid labour-wages periodicity } \\
\text { Paid labour-wages deduction } \\
\text { Wage gaps by sex, gender, nationality, cultural group, } \\
\text { and race } \\
\text { Paid labour-wages based on living location } \\
\text { Paid labour-minimum wage } \\
\text { Paid labour-health insurance } \\
\text { Safety-accidents and death } \\
\text { Safety-education and training } \\
\text { Labour union-rights } \\
\text { Labour union-affiliation } \\
\text { Working hours } \\
\text { Safety-appropriate equipment and availability } \\
\text { Paid leave-holidays and vacations } \\
\text { Employment freedom and justice } \\
\text { Access to technology } \\
\text { Access to research and development options } \\
\text { Relationship with violent conflicts, including war } \\
\text { Corruption and unethical practices }\end{array}$} & Quantitative & Negative \\
\hline & & Quantitative & Negative \\
\hline & & Semi-quantitative (Yes/No) & Yes \\
\hline & & Semi-quantitative (Yes/No) & No \\
\hline & & Quantitative & Negative \\
\hline & & Quantitative & Positive \\
\hline & & Quantitative & Negative \\
\hline & & Quantitative & Positive \\
\hline & & Quantitative & Negative \\
\hline & & Semi-quantitative (Yes/No) & Yes \\
\hline & & Semi-quantitative (Yes/No) & Yes \\
\hline & & Semi-quantitative (Yes/No) & Yes \\
\hline & & Semi-quantitative (Yes/No) & Yes \\
\hline & & Quantitative & Negative \\
\hline & & Quantitative & Positive \\
\hline & & Semi-quantitative (Yes/No) & Yes \\
\hline & & Semi-quantitative (Yes/No) & Yes \\
\hline & & Semi-quantitative (Yes/No) & Yes \\
\hline & & Semi-quantitative (Yes/No) & No \\
\hline & & Semi-quantitative (Yes/No) & No \\
\hline \multirow{4}{*}{ Society } & \multirow{4}{*}{$\begin{array}{c}\text { Sustainability and social responsibility-orientation } \\
\text { Sustainability and social responsibility-behaviour } \\
\text { Sustainability and social responsibility-economic } \\
\text { contribution to regions and nations } \\
\text { Sustainability and environmental } \\
\text { responsibility-promotion }\end{array}$} & Semi-quantitative (Yes/No) & Yes \\
\hline & & Semi-quantitative (Yes/No) & Yes \\
\hline & & Semi-quantitative (Scale 1 to 5 ) & Positive \\
\hline & & Semi-quantitative (Yes/No) & Yes \\
\hline
\end{tabular}

\subsection{2. "Famiglia di Maria" Foundation}

The strong bonds between the families and the "Famiglia di Maria" Foundation and the Foundation that hosts the project and the territory identified positive elements. Due to the activities organised in the foundation building, the contact between the hosting Foundation (Famiglia di Maria) and the families enables the Foundation to collect feedback coming from the families. Moreover, the performed activities always consider the participants' interests, hobbies, and skills. Thus, the participants can also share competencies during meetings and laboratories, manual activities, and information moments, showing the Foundation's respect for the local cultural heritage (one of the main indicators of this study is: "Project activities influence the sense of place and cultural heritage"). Indeed, all the interviewed family members stated that they would also attend the foundation activities not connected 
to the REC project, demonstrating that the sense of community born around the project is strong and goes beyond the economic gains and environmental goals.

Results of the assessment of "Project activities influence on health and safety indicator" (Appendix C) highlighted another positive impact of the trustful relationship between the "Famiglia di Maria" Foundation and families. A hub for vaccinations against COVID-19 was organised at the foundation building for the entire local community. The vaccination hub would have probably been equipped even if the Solidarity Oriented REC had not existed. Nevertheless, the project brought many new people to the Foundation. Thus, many individuals have information and access to health services, which are fragile in peripheral neighbourhoods.

\subsubsection{Project Perspective from Stakeholders' Interactions}

From the interviews and the meetings with the representatives of the "Famiglia di Maria" Foundation, the association "Legambiente", and the technical partner "3eee" Company, many obstacles were faced with starting the operation of the PV panels plant due to bureaucratic burdens. In particular, the local administrative authorities (public local institution stakeholders) raised landscape constraints based on historical buildings regulations limiting the installation of PV panels on rooftops. Therefore, the project schedule was delayed, even if the PV plant was ready to produce electricity. Another identified limit for REC's operability was the contrast between the local institutions and the key promoters of the project ("Famiglia di Maria" Foundation, the association "Legambiente", "3eee" Company. and Con il Sud Foundation) during the start-up phase of the project. Furthermore, the current legal impossibility to self-consume in RECs created questions about alternative legal frameworks in which self-consumption and different project governance of processes become possible.

Results from "3eee" Company data collection (Appendix B) showed some challenging elements. The first one is connected to the absence of trade union membership among workers (identified indicators: "Labour union-rights" and "Labour union-affiliation"), which is understandable considering the tiny dimension of the company. However, the risk of workers' rights was identified (Appendix C). The other challenge is related to the ethical indicator ("Sustainability and social responsibility-promotion" indicators, Appendix C). The company seems to respect standards and select partners and suppliers virtuously, even though no initiative has been undertaken to promote these good practices among partners and society in general (Appendices B and C). Therefore, the participation in the energy community project and the involvement of the "3eee" Company in the educational activities are likely to open possibilities for future proactivity. Additionally, results demonstrate that components of the plant come from sustainable production.

In addition to the s-LCA reported results, another important aspect was observed from the context and interaction among all stakeholders: the project's governance, which limits families' involvement in the decision process, is also a risk. Families' empowerment is still at a starting point, far from the everyday reality of well-established solidarity oriented association. There is still no place for essential decisions from below. The upcoming behaviour of the "Famiglia di Maria" Foundation might determine more involvement of families in the major decisions by reducing the level of management control over decisions in the near future. Meanwhile, related to the mission and main activities of the "Famiglia di Maria" Foundation, some initiatives were implemented about gender discrimination and female inclusion within the Solidarity Oriented REC project framework.

The initiatives against gender violence involve a music laboratory in which a song against violence was produced and recorded. Considering that all the participants in the laboratories are women, this result shows the positive and empowering impact of the project. Regarding female inclusion, women are the main actors in the investigated REC project. As often happens, projects with environmental and energy purposes have high participation by women due to the unfair distribution of job opportunities and, in general, the differences in public life between genders. Moreover, the diffused gender inequality 
pushes women to commit to family care and, for this reason, women are more available to engage in this kind of project. Gender inequality is even more relevant for disadvantaged territories, where depressed economies enlarge the gap to extremes. Therefore, energyrelated projects can represent an empowerment tool in these territories than elsewhere, especially for women [43].

The final remark from this preliminary s-LCA applied to the Solidarity Oriented REC highlights that cohesion is already present as a mature outcome. At the same time, awareness, governance opportunities, and technical competencies about the environmental value of the project are still outcomes to be realised through the course of future events and interactions. Certainly, RECs bring many opportunities to territories and local communities. However, the increase of RECs should not correspond to an intensification of electricity consumption and production because it comes from a clean source. Instead, the rise of RECs is desirable based mainly on achievable social awareness and opportunities for territories.

\subsection{Life Cycle Assessment (LCA)}

The environmental burdens for each investigated impact category of the electricity produced by the Italian electricity mix and the PV panels installed at the Solidarity Oriented REC of San Giovanni a Teduccio are reported in Table 4.

Table 4. Characterised impacts calculated for the evaluated PV plant compared to the Italian electricity mix-functional unit $1 \mathrm{kWh}$ of electricity produced.

\begin{tabular}{|c|c|c|c|c|}
\hline Impact Categories & Abbreviation & Units & Italian Electricity Mix & $\begin{array}{l}\text { PV Plant } \\
\text { (REC) }\end{array}$ \\
\hline Global warming & GWP & $\mathrm{kg} \mathrm{CO} 2 \mathrm{eq}$ & $4.31 \times 10^{-1}$ & $1.59 \times 10^{-1}$ \\
\hline Stratospheric ozone depletion & ODP & $\mathrm{kg} \mathrm{CFC11} \mathrm{eq}$ & $3.40 \times 10^{-7}$ & $1.02 \times 10^{-7}$ \\
\hline Ionising radiation & IRP & $\mathrm{kBq}$ Co-60 eq & $4.88 \times 10^{-2}$ & $1.00 \times 10^{-3}$ \\
\hline Ozone formation, human health & OFHP & kg NOx eq & $8.11 \times 10^{-4}$ & $2.85 \times 10^{-4}$ \\
\hline Fine particulate matter formation & PMFP & $\mathrm{kg} \mathrm{PM}_{2.5} \mathrm{eq}$ & $5.43 \times 10^{-4}$ & $1.67 \times 10^{-4}$ \\
\hline Ozone formation, terrestrial ecosystems & OFTP & kg NOx eq & $8.25 \times 10^{-4}$ & $2.89 \times 10^{-4}$ \\
\hline Terrestrial acidification & TAP & $\mathrm{kg} \mathrm{SO}_{2} \mathrm{eq}$ & $1.58 \times 10^{-3}$ & $4.95 \times 10^{-4}$ \\
\hline Freshwater eutrophication & FEP & $\mathrm{kg} \mathrm{P}$ eq & $1.36 \times 10^{-4}$ & $3.63 \times 10^{-5}$ \\
\hline Marine eutrophication & MEP & $\mathrm{kg} \mathrm{N} \mathrm{eq}$ & $1.28 \times 10^{-5}$ & $3.70 \times 10^{-6}$ \\
\hline Terrestrial ecotoxicity & TETP & kg 1,4-DCB & 1.23 & $1.16 \times 10^{-1}$ \\
\hline Freshwater ecotoxicity & FETP & kg 1,4-DCB & $4.24 \times 10^{-2}$ & $2.38 \times 10^{-3}$ \\
\hline Marine ecotoxicity & METP & $\mathrm{kg} 1,4-\mathrm{DCB}$ & $5.28 \times 10^{-2}$ & $3.22 \times 10^{-3}$ \\
\hline Human carcinogenic toxicity & НCTP & $\operatorname{kg} 1,4-\mathrm{DCB}$ & $1.42 \times 10^{-2}$ & $3.06 \times 10^{-3}$ \\
\hline Human non-carcinogenic toxicity & HNTP & kg 1,4-DCB & $3.95 \times 10^{-1}$ & $7.33 \times 10^{-2}$ \\
\hline Land use & LUP & $\mathrm{m}^{2} \mathrm{a}$ crop eq & $1.71 \times 10^{-1}$ & $6.03 \times 10^{-2}$ \\
\hline Mineral resource scarcity & MSP & $\mathrm{kgCu}$ eq & $9.24 \times 10^{-4}$ & $1.13 \times 10^{-4}$ \\
\hline Fossil resource scarcity & FSP & kg oil eq & $1.30 \times 10^{-1}$ & $4.92 \times 10^{-2}$ \\
\hline Water consumption & WCP & $\mathrm{m}^{3}$ & $8.99 \times 10^{-3}$ & $3.03 \times 10^{-3}$ \\
\hline
\end{tabular}

These results show an overall average reduction of impacts of $76 \%$ for the electricity generated by the PV plant of the REC compared to the Italian electricity mix. The significant decreases (Figure 3 and Table 4) are shown in ionising radiation (IRP) $98 \%$, followed by 94\% in freshwater ecotoxicity (FETP) and marine ecotoxicity (METP), 91\% in terrestrial ecotoxicity (TETP), and 88\% in mineral resource scarcity (MSP). 


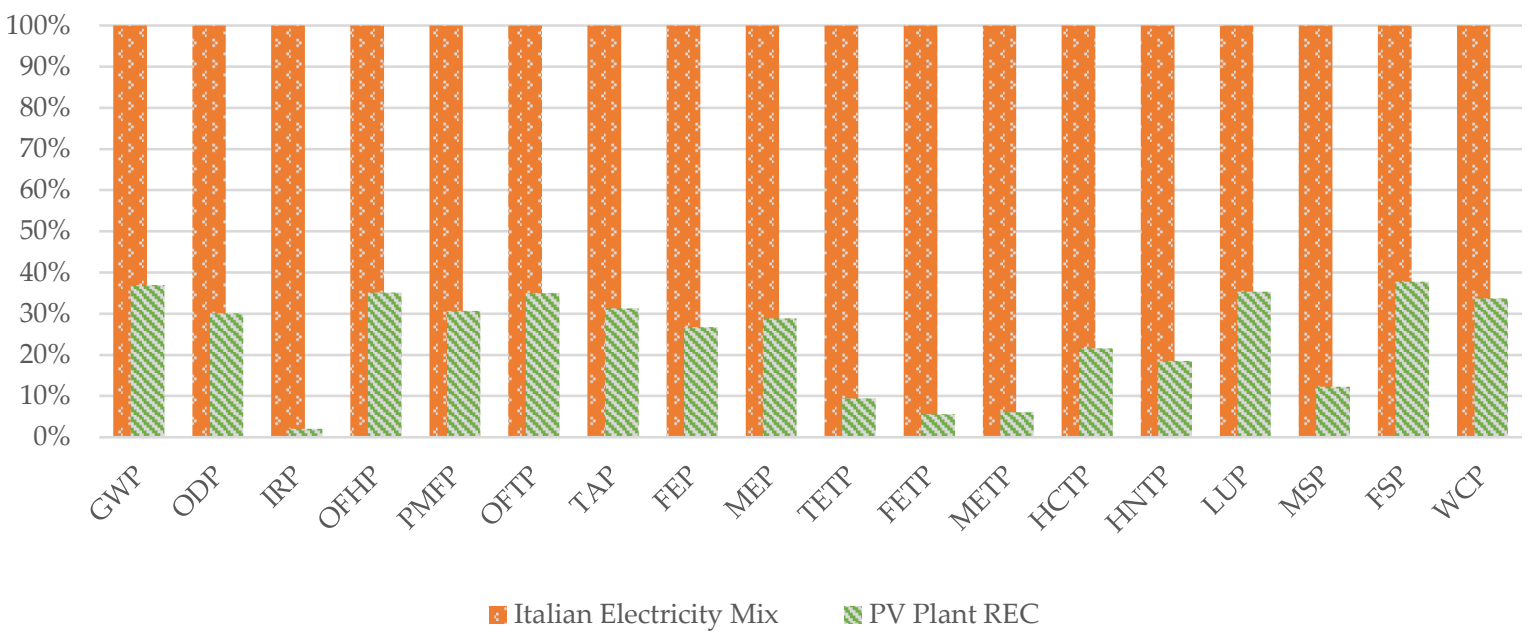

Figure 3. LCA characterisation graph showing the comparison between electricity produced by the Italian electricity mix and the evaluated PV plant (functional unit $1 \mathrm{kWh}$ of electricity produced).

The normalised impacts (Table 5) for the electricity generated by the Italian mix and the PV plant of the Solidarity Oriented REC show that the most impacted categories are the marine ecotoxicity (METP, 0.051 and 0.003 for Italian mix and the PV plant, respectively), freshwater ecotoxicity (FETP, 0.034 and 0.002 for Italian mix and the PV plant, respectively), human carcinogenic toxicity (HCTP, 0.005 and 0.001 for Italian mix and the PV plant, respectively), and human non-carcinogenic toxicity (HNTP, 0.002 and 0.0004 for Italian mix and the PV plant, respectively). These results are in line with pertinent scientific literature reporting reduced impacts for PV installations on toxicity impact categories (human, marine, and freshwater) [44-47].

Table 5. Normalised impacts calculated for the evaluated PV plant compared to the Italian electricity mix (functional unit $1 \mathrm{kWh}$ of electricity produced).

\begin{tabular}{cccc}
\hline Impact Categories & Abbreviation & Italian Electricity Mix & PV Plant (REC) \\
\hline Global warming & GWP & $5.401 \times 10^{-5}$ & $1.997 \times 10^{-5}$ \\
Stratospheric ozone depletion & ODP & $5.679 \times 10^{-6}$ & $1.711 \times 10^{-6}$ \\
Ionising radiation & IRP & $1.015 \times 10^{-4}$ & $2.086 \times 10^{-6}$ \\
Ozone formation, human health & OFHP & $3.941 \times 10^{-5}$ & $1.383 \times 10^{-5}$ \\
Fine particulate matter formation & PMFP & $2.123 \times 10^{-5}$ & $6.520 \times 10^{-6}$ \\
Ozone formation, terrestrial ecosystems & OFTP & $4.644 \times 10^{-5}$ & $1.629 \times 10^{-5}$ \\
Terrestrial acidification & TAP & $3.857 \times 10^{-5}$ & $1.208 \times 10^{-5}$ \\
Freshwater eutrophication & FEP & $2.096 \times 10^{-4}$ & $5.597 \times 10^{-5}$ \\
Marine eutrophication & MEP & $2.779 \times 10^{-6}$ & $8.020 \times 10^{-7}$ \\
Terrestrial ecotoxicity & TETP & $1.184 \times 10^{-3}$ & $1.122 \times 10^{-4}$ \\
Freshwater ecotoxicity & FETP & $3.454 \times 10^{-2}$ & $1.941 \times 10^{-3}$ \\
Marine ecotoxicity & METP & $5.112 \times 10^{-2}$ & $3.125 \times 10^{-3}$ \\
Human carcinogenic toxicity & HCTP & $5.112 \times 10^{-3}$ & $1.104 \times 10^{-3}$ \\
Human non-carcinogenic toxicity & HNTP & $2.649 \times 10^{-3}$ & $4.917 \times 10^{-4}$ \\
Land use & LUP & $2.766 \times 10^{-5}$ & $9.766 \times 10^{-6}$ \\
Mineral resource scarcity & MSP & $7.694 \times 10^{-9}$ & $9.432 \times 10^{-10}$ \\
Fossil resource scarcity & FSP & $1.329 \times 10^{-4}$ & $5.019 \times 10^{-5}$
\end{tabular}

Characterised and normalised results underline that the electricity generated by PV panels installed in the Solidarity Oriented REC reduces environmental burdens and is potentially considered an environmentally friendly energy source.

The electricity produced by the Solidarity Oriented REC PV panels reduces the environmental impact (Table 6). The absolute benefit value was calculated by subtracting the 
environmental burdens (values reported in Table 4) of the electricity produced by the PV plant from the electricity supplied by the Italian grid.

Table 6. Annual environmental benefits are sorted in descending order of absolute benefit value.

\begin{tabular}{|c|c|c|c|c|c|c|}
\hline \multirow{3}{*}{$\begin{array}{c}\text { Impact } \\
\text { Categories }\end{array}$} & \multirow{3}{*}{ Units } & \multirow{3}{*}{$\begin{array}{c}\text { Absolute } \\
\text { Benefit Value } \\
\text { of } 1 \mathrm{kWh} *\end{array}$} & \multirow{3}{*}{$\begin{array}{c}\text { Project } \\
\text { Perspective } \\
\\
\text { Solidarity } \\
\text { Oriented REC }\end{array}$} & \multicolumn{3}{|c|}{ Families Perspective } \\
\hline & & & & \multicolumn{3}{|c|}{ Self-Consumption Scenario } \\
\hline & & & & $\begin{array}{c}\text { BAU } \\
\text { Scenario }\end{array}$ & $\begin{array}{l}\text { Electricity } \\
\text { Consumed }\end{array}$ & $\begin{array}{l}\text { Electricity } \\
\text { Surplus Sold } \\
\text { to the Grid }\end{array}$ \\
\hline TETP & $\mathrm{kg} 1,4-\mathrm{DCB}$ & 1.11 & $1.28 \times 10^{5}$ & $3.21 \times 10^{3}$ & $3.11 \times 10^{2}$ & $2.90 \times 10^{3}$ \\
\hline HNTP & kg 1,4-DCB & $3.22 \times 10^{-1}$ & $3.71 \times 10^{4}$ & $9.28 \times 10^{2}$ & $9.00 \times 10$ & $8.38 \times 10^{2}$ \\
\hline GWP & $\mathrm{kgCO} \mathrm{CO}_{2} \mathrm{eq}$ & $2.72 \times 10^{-1}$ & $3.14 \times 10^{4}$ & $7.85 \times 10^{2}$ & $7.61 \times 10$ & $7.09 \times 10^{2}$ \\
\hline LUP & $\mathrm{m}^{2} \mathrm{a}$ crop eq & $1.10 \times 10^{-1}$ & $1.27 \times 10^{4}$ & $3.19 \times 10^{2}$ & $3.09 \times 10$ & $2.88 \times 10^{2}$ \\
\hline FSP & kg oil eq & $8.11 \times 10^{-2}$ & $9.36 \times 10^{3}$ & $2.34 \times 10^{2}$ & $2.27 \times 10$ & $2.11 \times 10^{2}$ \\
\hline METP & kg 1,4-DCB & $4.95 \times 10^{-2}$ & $5.72 \times 10^{3}$ & $1.43 \times 10^{2}$ & $1.39 \times 10$ & $1.29 \times 10^{2}$ \\
\hline IRP & kBq Co-60 eq & $4.78 \times 10^{-2}$ & $5.52 \times 10^{3}$ & $1.38 \times 10^{2}$ & $1.34 \times 10$ & $1.25 \times 10^{2}$ \\
\hline FETP & $\mathrm{kg} 1,4-\mathrm{DCB}$ & $4.00 \times 10^{-2}$ & $4.62 \times 10^{3}$ & $1.15 \times 10^{2}$ & $1.12 \times 10$ & $1.04 \times 10^{2}$ \\
\hline НСТР & kg 1,4-DCB & $1.11 \times 10^{-2}$ & $1.28 \times 10^{3}$ & $3.20 \times 10$ & 3.11 & $2.89 \times 10$ \\
\hline $\mathrm{WCP}$ & $\mathrm{m}^{3}$ & $5.96 \times 10^{-3}$ & $6.88 \times 10^{2}$ & $1.72 \times 10$ & 1.67 & $1.55 \times 10$ \\
\hline TAP & $\mathrm{kg} \mathrm{SO}_{2} \mathrm{eq}$ & $1.09 \times 10^{-3}$ & $1.25 \times 10^{2}$ & 3.13 & $3.04 \times 10^{-1}$ & 2.83 \\
\hline MSP & $\mathrm{kg} \mathrm{Cu} \mathrm{eq}$ & $8.10 \times 10^{-4}$ & $9.35 \times 10$ & 2.34 & $2.27 \times 10^{-1}$ & 2.11 \\
\hline OFTP & kg NOx eq & $5.35 \times 10^{-4}$ & $6.18 \times 10$ & 1.55 & $1.50 \times 10^{-1}$ & 1.40 \\
\hline OFHP & kg NOx eq & $5.26 \times 10^{-4}$ & $6.08 \times 10$ & 1.52 & $1.47 \times 10^{-1}$ & 1.37 \\
\hline PMFP & $\mathrm{kg} \mathrm{PM}_{2.5} \mathrm{eq}$ & $3.76 \times 10^{-4}$ & $4.34 \times 10$ & 1.09 & $1.05 \times 10^{-1}$ & $9.81 \times 10^{-1}$ \\
\hline FEP & $\mathrm{kg} \mathrm{P} \mathrm{eq}$ & $9.98 \times 10^{-5}$ & $1.15 \times 10$ & $2.88 \times 10^{-1}$ & $2.79 \times 10^{-2}$ & $2.60 \times 10^{-1}$ \\
\hline MEP & $\mathrm{kg} \mathrm{N} \mathrm{eq}$ & $9.11 \times 10^{-6}$ & 1.05 & $2.63 \times 10^{-2}$ & $2.55 \times 10^{-3}$ & $2.37 \times 10^{-2}$ \\
\hline ODP & $\mathrm{kg} \mathrm{CFC11} \mathrm{eq}$ & $2.38 \times 10^{-7}$ & $2.74 \times 10^{-2}$ & $6.86 \times 10^{-4}$ & $6.65 \times 10^{-5}$ & $6.19 \times 10^{-4}$ \\
\hline
\end{tabular}

* Reduction of families' environmental impacts by consuming electricity from photovoltaic panels instead of electricity from the Italian energy grid mix (absolute value).

The Project and Families perspectives consider all 40 families planned to be involved in the Solidarity Oriented REC (Table 6). The project perspective accounts for the total PV electricity produced in one year by the installed PV plant: 115,434 kWh/year (primary data collected during the interview with a manager of the "3eee" Company [39]). The families perspective accounts for the average annual electricity consumption of a family part of the Solidarity Oriented REC (an average family in the neighbourhood consumes $280 \mathrm{kWh} /$ year [39]). Therefore, the project benefit value for each investigated impact category was calculated to underline the potential environmental advantages after one year of project operation (project perspective: PV electricity entirely sold to the national grid). Shifting to the Families perspective, scenarios were built based on the share of electricity self-consumed and sold to the Italian grid. In the business as usual (BAU) scenario, 100\% of the PV electricity produced is sold to the grid. Each family receives the same income from the electricity company for this transaction. In contrast, in the self-consumption scenario, families ( 40 families) self-consume the electricity produced by the PV plant. The self-consumed electricity amounts to approximately $10 \%$ of the total electricity produced by the Solidarity Oriented REC. In this case, only the electricity surplus is sold to the grid, and the families receive two advantages: no expenses for electricity and a small profit are still recorded. As highlighted in recent literature [47], shifting the perspective shows that, even if the environmental benefits between the two REC operational models (entirely sold to the grid and partially self-consumed electricity) are the same, self-consuming energy is also economically convenient. However, self-consumption means acquiring batteries to accumulate electricity. Thus, results might be worse than the current assessed one, on some specific impact categories, due to the need to account for new materials and services to enable self-consuming electricity. 


\section{Conclusions}

This study is characterised by a specificity: whereas the environmental effects are almost exclusively related to electricity production (single product), the social consequences are pervasive and disseminated all over the project of the Solidarity Oriented REC of San Giovanni a Teduccio, denoting a complex object of analysis with many stakeholders and outcomes. This complexity also enables the formulation of political considerations about ECs addressing the fundamental issue of energy justice as a crucial component of environmental justice. Therefore, ECs should be encouraged, and their potential should be studied and disseminated. However, the thirst for the quantitative expansion of renewable energy generation should be turned into a qualitative shift, driving to a resilient transition towards an ethical, shared, empowering, accessible, and clean energy.

The s-LCA investigation demonstrated a great sense of community among the prosumers. However, it is still impossible to state whether the project produces real awareness and empowerment. Nevertheless, the LCA results support the s-LCA outcomes, highlighting the self-consumption scenario as a feasible alternative for energy justice.

Additional considerations were made about the Italian legal framework regarding the self-consumption model: peer to peer sharing systems allow the transactions among producers and consumers without an intermediary in a democratic and consensus-based way. Therefore, the self-consumption model represents an alternative system for communities to: (i) empower themselves, (ii) get complete economic independence from the energy supply companies, and (iii) develop sharing practices outside of the market competition.

Author Contributions: S.K.-conceptualisation, methodology, formal analysis, s-LCA investigation, writing - original draft preparation; M.O.-conceptualisation, methodology, formal analysis, LCA investigation, writing —original draft preparation, writing — review and editing; C.V.-investigation, writing-original draft preparation; G.O.-conceptualisation, methodology; A.Z.-writing-review and editing, reviewing, validation, project administration. All authors have read and agreed to the published version of the manuscript.

Funding: This project has received funding from the European Union's Horizon 2020 research and innovation programme under the Marie Skłodowska-Curie Innovative Training Networks (H2020MSCA-ITN-2018) scheme, grant agreement number 814247 (ReTraCE).

Institutional Review Board Statement: This research has obtained ethical approval according to the procedures and standards of University Parthenope of Napoli.

Informed Consent Statement: Informed consent was obtained from all subjects involved in the study.

Acknowledgments: A special thank goes to the "Famiglia di Maria" Foundation, the "Con il Sud" Foundation, the Association "Legambiente Campania", the "3eee" Company, and to the women of the Energy Community of San Giovanni a Teduccio.

Conflicts of Interest: The authors declare no conflict of interest.

\section{Appendix A}

The s-LCA questionnaire for the families in English (the original questionnaire in Italian is available online at: https: / www.survio.com/survey/d/N8X4Q8F0E3P5O1Y2L; accessed on: 16 February 2022).

Families Energy Community San Giovanni

Dear Sir or Madam,

Please take a few minutes of your time to complete the following survey.

1. Gender

- Woman

- Man

- Other

2. How old are you? Type one or more words Do you live here in the neighbourhood? Choose an answer 
- Yes

- $\quad$ No

3. How did you get to know "Famiglia di Maria"? Choose one or more answers

- Some people who come to the Foundation have told me about it.

- For the activities they do with children: I bring my child/children here.

- From the internet/TV/Newspapers.

- I didn't know them: they contacted me for the Energy Community.

- Other.

4. Do you currently attend the Foundation only for the Energy Community project or also for other activities? Choose an answer

- Only for activities related to the Energy Community.

- For something else too.

5. What is a community for you? Choose an answer

- A group of people who come together to achieve a goal.

- A group of people who come together to improve their own life conditions and those of others.

- A group of people who participate in the collective wellbeing of their territory.

6. What value does ecology/respect for the environment have for you? Choose an answer

- It is important, but it is not a priority.

- It is fundamental and a priority.

- It is essential, that is, without it, there is no true wellbeing.

7. Is it necessary to produce and consume clean energy today? Choose an answer

- No, it is just a topic of the moment, but it is indifferent.

- Yes, because energy is needed for life.

- Yes, because its production and consumption are among the main factors of atmospheric pollution.

8. Has the way you see respect for the environment and what community means have changed since you were part of the project? Choose an answer

- Yes.

- No.

9. Why did you decide to enter the Energy Community project? Choose one or more answers

- To have the economic advantage of receiving a sum of money at the end of the year.

- To be part of a project with other people from the neighbourhood: I enjoy being in a group.

- To do something good for the environment and produce clean energy.

- To do something good for my neighbourhood is always described as dangerous and degraded.

10. What is an Energy Community, in your opinion? Choose one or more answers

- One way to demonstrate that the problem of pollution can be solved with clean energy and can serve as an example for giving birth to other communities.

- One way to show that people can organise themselves even if institutions leave us alone and can serve as an example for other places with problems.

- Just a nice project to make people talk about a disadvantaged neighbourhood, but things will not change on a general level, neither here nor in other places.

- It's a nice project to make people talk about a disadvantaged neighbourhood, but it can only change things here, others in other places will not notice it, or at least they will not do anything similar. 
11. Do you know other examples of Energy Community in other places? Choose an answer

- Yes.

- No.

- I've heard of it, but I don't know where they are.

Let's rate the different reasons for joining an Energy Community: how many stars would you give to this?

12. Economic advantage: the money we will earn at the end of the year.

13. Being part of a group and being able to meet new people.

14. Doing something important for the environment.

15. Become an example for other difficult places like San Giovanni.

16. Learn more about environmental problems and solutions.

17. Changing my neighbourhood and improving it together with others, because together we can also do many other good things for San Giovanni.

18. Becoming famous and going on TV because now everyone is talking about our project.

19. Now, let's put the same reasons in order as before, from the most important to the least important. Change the order of preference (1-most important, last-least important)

- Economic advantage: the money we will earn at the end of the year.

- Becoming famous and going on TV because now everyone is talking about our project.

- Understanding more about environmental problems and solutions.

- Being part of a group and meeting new people.

- Doing something important for the environment.

- Becoming an example for other difficult places like San Giovanni.

- Changing my neighbourhood and improving it together with others, because together we can also do many other good things for San Giovanni.

20. What is changing in the neighbourhood thanks to the project? Choose one or more answers in each row

They know a lot more about the environment thanks to the project.

\section{They are happy with the project.}

They are happy with the project, but they know nothing more about the environment than before.

\author{
They don't care \\ about the project \\ or the environment \\ in general.
}

They are unhappy with the project.

\footnotetext{
The people of the Energy

Community

The people of San

Giovanni who are

not in the project

The people outside

San Giovanni
}

21. Do you think there will be someone in the neighbourhood who will not be happy with the project? Choose an answer

- Yes, many.

- Yes, but few.

- No, they will all be happy with the project.

22. If someone in the neighbourhood is not happy with the project, what could be the reason? Choose one or more answers

- Because they don't know what it is and they talk without knowing.

- Because they are not interested in the environment and in changing the neighbourhood.

- Because they have not been involved and are envious. 
- Because they don't want things to change for the better in the neighbourhood.

23. How would you solve the problem of people who are possibly against the project? Choose one or more answers

- I would like to meet them and explain the importance of the project.

- I would invite them here to involve them in some activities and show them they are interesting.

- I would not consider them because I am not interested in explaining to these people.

- I would explain to someone; some others cannot be convinced.

24. Do you like having all this attention from newspapers and TV? Choose an answer

- Yes, because what's going on is funny and I like being popular.

- Yes, because they will talk about our community and other places can do the same in this way.

25. In your opinion, what will change in the near future thanks to the project? Choose one or more answers

- Anything.

- Few things, but it is already something.

- Few things that won't solve anything.

- Many things can open the doors to better development for San Giovanni.

26. The money you will earn in the project will be: Choose an answer

- Little stuff, but better than nothing.

- An important help we need.

- Little stuff, but an important symbol for change

27. What will you do with the money you will earn in the project? Choose one or more answers

- I will use them for myself.

- I will keep them.

- I will use them for household expenses.

28. How are decisions made in the project? Choose an answer

- We meet and talk to decide together.

- The Foundation understands more and decides, then explains the decisions made.

- The Foundation decides on its own without talking to us; we are so confident that everything will be fine following their decisions.

- For now, the Foundation decides, but when we better understand the issues of the project, we will always decide together.

29. How do you feel about participating in the project? Choose an answer

- I feel that I participate more in the life of the neighbourhood and that I can change it.

- I do not decide anything for the neighbourhood, but I participate in a good project and I am happy to be part of it anyway.

- Nothing has changed compared to how I felt before joining the project.

30. Would you have any ideas to put into the project to do something else? Choose an answer

- No, things are fine this way.

- Yes, I would like to propose doing something else, but I know that it is impossible.

- Yes, I would also like to propose something else and I think that I will be able to make this proposal in the future.

31. Choose one of the following sentences that express your thoughts: Choose an answer

- This project is only positive for me, the neighbourhood and everyone and nothing worry me neither for the present nor for the future. 
- This project is only positive for me, the neighbourhood and everyone, but it worries me that we will not be able to get it started due to bureaucratic problems with the municipality.

- This project is only positive for me, the neighbourhood and everyone, but it worries me that we will not be able to make it work after the departure due to some neighbourhood residents who will create problems.

- This project is good for me, the neighbourhood and everyone, but I'm afraid we won't be able to make it work once it starts.

Thank you for participating!

Serena Kaiser,

Department of Science and Technology "Parthenope" University

\section{Appendix B}

Synthesis of the Meetings, Interviews and Questionnaires-Other Stakeholders

1. "Famiglia di Maria" Foundation

The meetings with the Foundation "Famiglia di Maria" have been both live meetings and remote interviews. Therefore, it has been possible to talk to the President and other operators. The main aspects touched were the project's origins, the story of the Foundation and the relation with the territory and the people, and the activities within and outside the Energy Community project.

About the families, the Foundation has explained how they have been chosen and why and the motivation of the families to join the project.

Elements about feedback mechanisms and privacy have been explained.

The Foundation has always been an intermediary between the authors and the families.

A questionnaire has been used, but it has only been a base for wider conversations. However, it can be useful to introduce it, to have elements about the key points of the meetings:

- Who came up with the idea to form an Energy Community and why?

- According to which criteria were the families chosen in the neighbourhood to be involved?

- $\quad$ Are families expected to adhere to the values, principles, and aims of the project in addition to the requirements through which they were chosen? If so, how has this been observed?

- What socio-economic background do the families come from?

- Were the families involved in any part of the design?

- In involved families, have there been people more active and responsible for the dialogue with you and the decision to join? (More adults/older/young people/males/females ... ?)

- Were there families who refused to join? If so, why?

- What were, in your opinion, the main reasons that drove families to join the project?

- $\quad$ Do you perceive that other reasons have been added to the initial reasons as a result of the accession?

- What kind of consequences are expected once the project starts? (economic, social, cultural ... ) (this question belongs to the first period of the research when the project had not started yet).

- Have you thought of introducing a feedback mechanism for families as a tool to express their impressions about the project?

- Is the privacy of the participants protected?

- Can families have access, at any time, to the documents and any tool that is useful for a transparent understanding of the objectives and functioning of the project?

- Has the project created/will it create any employment opportunities on the territory?

- When will the cultural activities start? (question from before the project started).

- What kind of cultural activities are you planning to develop? (question from before the project started).

- What will the topics of the cultural activities be? 
- Will participants in cultural activities be involved only as learners/audience, or can they propose cultural sharing and exchange activities, topics they are interested in, requests from below, etc ... ?

- Is there any plan, at a certain stage in the project's development, e.g., during/after cultural activities, to initiate or-if already active- to encourage the participation of families in the decision-making process concerning the development of the project?

- In your opinion, what are the main benefits that will arise in the territory, even beyond the families directly involved in the project?

- $\quad$ Are you planning to link the project only to environmental issues or extend it to the possibility of dealing with other socially sensitive issues?

- Is there a perception that this project could prevent and/or mitigate not only economic and energy poverty, but also violence, crime, and local tensions?

- $\quad$ Is anyone outside your territory interested in your practices and has contacted you? If so, who and why?

- Would you be interested in networking with other similar realities?

2. "3eee" Company

In addition to meetings with the Foundation "Famiglia di Maria", several meetings and conversations with the "3eee" Company were held, both live and remote. As in the previous case, a set of questions had been prepared and can be useful to be presented here, even though they only represent a base for wider conversations.

- $\quad$ How many workers are there in your company?

- How many are men, how many are women? (In the absence of precise data, give an approximate answer)

- $\quad$ In which jobs are men more represented, in which are women?

- How many workers were employed to install the photovoltaic panels used for the project of Energy Community of San Giovanni a Teduccio?

- How many panels were assembled for the project?

- Would it be possible to know how many working hours were needed to install each panel (if not, do you know the total amount of working hours, so that you can calculate the hours for a single panel)?

- Where were the panels (or the different components) produced?

- Do you know the company that makes it?

- Which of these statements does your company represent? (you can tick multiple boxes):

- The majority of workers are employed on an indefinite basis;

- The majority of workers are employed on a fixed-term basis;

- $\quad$ Some workers are hired on a project basis (what number out of the total?);

- Some employees are interns (how many compared to the number of employees hired? on__).

- $\quad$ If there are interns, how many have been hired in the last period (about five years)? (__ recruited out of a total of trainees);

- Given the same skills and qualifications, which of these factors are, in your opinion, the most important for recruitment to the company? (Give a mark from 0 to 5 in parentheses for each element)

- $\quad$ Age [ ];

- General [ ];

- $\quad$ Previous experience [ ];

- Nationality [ ];

- Disability [ ];

- Knowledge of foreign languages [ ].

- Could you express YES/NO to the following statements?

- Safety at the workplace is respected (installations, emergency procedures ... )

- I have received and am receiving information and training on risk and safety YES NO; 
- The spaces are suitable and comfortable YES NO;

- The demands of the company are clear YES NO;

- I have been pressured or experienced unpleasant situations because of the person who runs the company YES NO;

- I have sometimes been pressured or experienced unpleasant situations by other colleagues YES NO;

- I can take enough breaks YES NO;

- The work rates are sustainable YES NO;

My relationship with executives is:

- $\quad \operatorname{good} Y E S N O$;

- dialectical YES NO;

- mutually collaborative YES NO;

- respectful YES NO;

My relationship with other colleagues is:

- pleasant YES NO;

- competitive YES NO;

- of team YES NO;

- fair YES NO.

- How would you define the relationship between your work and your pay?

- Adequate; Slightly inadequate; Totally inadequate.

- How would you define the distribution of workload in the company?

- Adequate; Slightly inadequate; Totally inadequate.

- How would you define the distribution of the burden of responsibility within the company?

- Adequate; Slightly inadequate; Totally inadequate.

- How would you define the company's respect for different trade union memberships?

- There is respect for every union membership, without any difference;

- There is respect for all memberships, but some trade unions are better considered;

- Employees are discouraged from joining trade unions in general;

- Workers are discouraged from joining certain trade unions.

- $\quad$ Regarding the S. Giovanni a Teduccio Energy Community project, could you give an order of importance to the reasons that led, in your opinion, the company to participate, among the following options? (Insert a number in the brackets next to each reason, expressing an order of importance):

- Environmental purposes (_);

- Involvement of the inhabitants for the empowerment and awareness of local communities (_);

- Consequences on society at a general level (_);

- Positive economic achievements for project participants (__);

- Positive economic achievements for the company;

- Positive marketing purpose for the company (_).

- Has anyone from the company met the families involved in the project?

- Will you also participate in the environmental training phase?

- Will you participate in other phases of the project?

- If so, which ones?

- Are you currently involved in other projects with relevant social objectives?

- If so, could you tell us briefly?

\section{Appendix C}

Social Life Cycle Assessment Results 
Table A1. s-LCA results

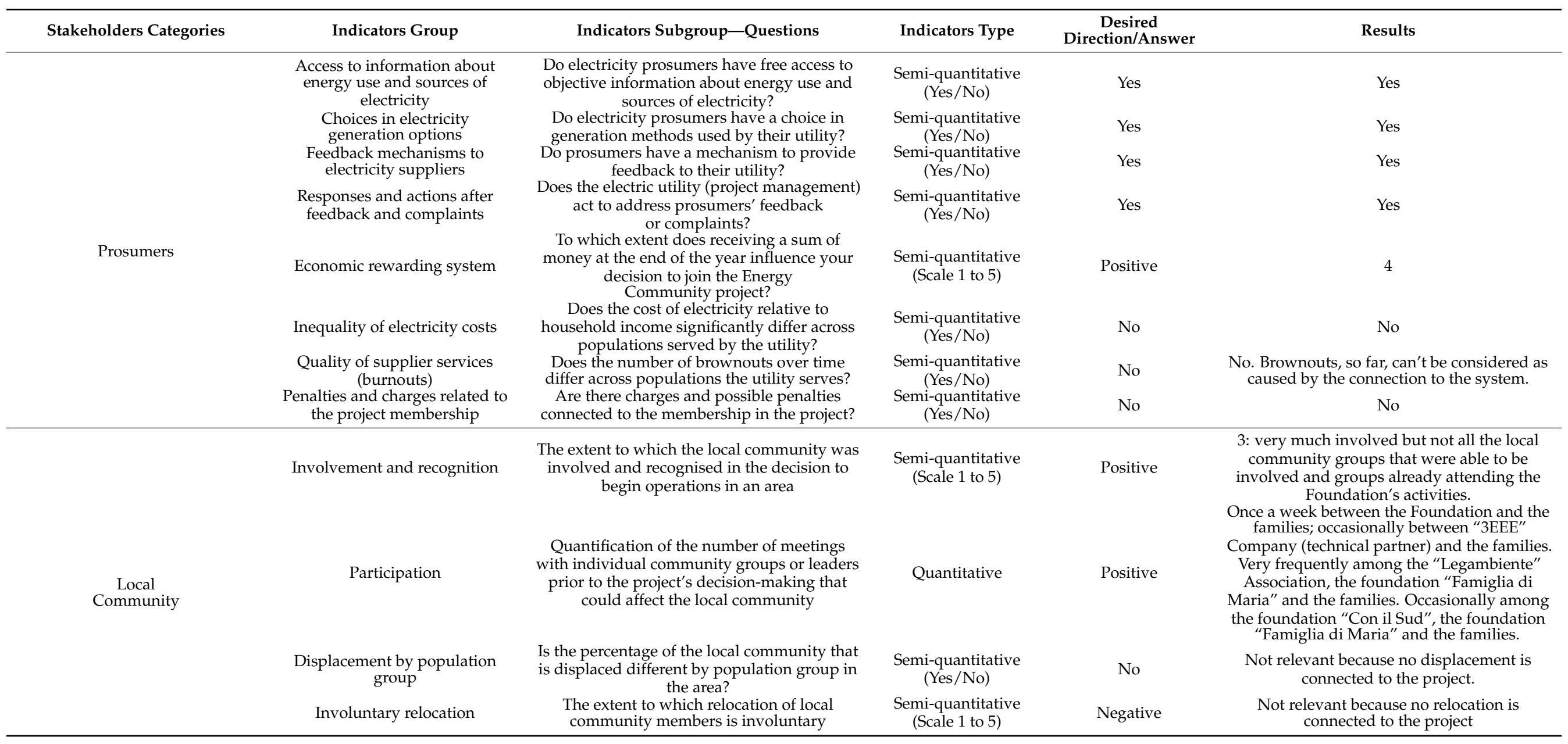


Table A1. Cont.

\begin{tabular}{|c|c|c|c|c|c|}
\hline Stakeholders Categories & Indicators Group & Indicators Subgroup-Questions & Indicators Type & $\begin{array}{c}\text { Desired } \\
\text { Direction/Answer }\end{array}$ & Results \\
\hline \multirow{8}{*}{$\begin{array}{c}\text { Local } \\
\text { Community (cont.) }\end{array}$} & Land and resources ownership & $\begin{array}{l}\text { Quantification of the percentage of the } \\
\text { resources in an area, including land, used by } \\
\text { the company that is owned by members of the } \\
\text { local community }\end{array}$ & Quantitative & Positive & $0 \%$ \\
\hline & Resources and electricity access & $\begin{array}{c}\text { Does the local community still retain access to } \\
\text { raw materials extracted at a site or have } \\
\text { access to the final product (electricity) } \\
\text { generated at a site? }\end{array}$ & $\begin{array}{l}\text { Semi-quantitative } \\
\quad \text { (Yes/No) }\end{array}$ & Yes & $\begin{array}{l}\text { Yes (only about electricity generated: there are } \\
\text { no raw materials to be extracted). }\end{array}$ \\
\hline & $\begin{array}{l}\text { Project activities influence the } \\
\text { sense of place and cultural } \\
\text { heritage }\end{array}$ & $\begin{array}{l}\text { Extent to which the activities of the project } \\
\text { either positively or negatively affect the local } \\
\text { community's sense of place and } \\
\text { cultural heritage }\end{array}$ & $\begin{array}{l}\text { Semi-quantitative } \\
\quad \text { (Scale } 1 \text { to } 5 \text { ) }\end{array}$ & Positive & $\begin{array}{l}\text { 5-all the activities aimed at enhancing } \\
\text { cultural heritage and bonds among local } \\
\text { community members and the territory. }\end{array}$ \\
\hline & $\begin{array}{l}\text { Project activities influence health } \\
\text { and safety }\end{array}$ & $\begin{array}{l}\text { Quantification of the health and safety } \\
\text { impacts on local community members by the } \\
\text { activities of the project }\end{array}$ & $\begin{array}{l}\text { Semi-qualitative } \\
\text { (Poor/High) }\end{array}$ & High & $\begin{array}{l}\text { High-highly positive due to initiatives } \\
\text { performed (and currently performing) within } \\
\text { the project, in particular: access to COVID-19 } \\
\text { vaccinations; initiatives against gender } \\
\text { violence. }\end{array}$ \\
\hline & $\begin{array}{l}\text { Availability of } \\
\text { project information }\end{array}$ & $\begin{array}{l}\text { Is project information available in all } \\
\text { local languages? }\end{array}$ & $\begin{array}{l}\text { Semi-quantitative } \\
\text { (Yes/No) }\end{array}$ & Yes & Yes \\
\hline & Access to project information & $\begin{array}{l}\text { Is project information easily accessible for } \\
\text { local community members? }\end{array}$ & $\begin{array}{l}\text { Semi-quantitative } \\
\quad \text { (Yes/No) }\end{array}$ & Yes & $\begin{array}{l}\text { Yes, but mainly for community members who } \\
\text { are also members of the project or for } \\
\text { individuals attending activities at the } \\
\text { "Famiglia di Maria" Foundation for other } \\
\text { reasons. }\end{array}$ \\
\hline & $\begin{array}{l}\text { Project policies for local culture } \\
\text { preservation and promotion }\end{array}$ & $\begin{array}{l}\text { Does the project have and enact policies that } \\
\text { show respect for local culture, including } \\
\text { observance of cultural events? }\end{array}$ & $\begin{array}{l}\text { Semi-quantitative } \\
\quad \text { (Yes/No) }\end{array}$ & Yes & $\begin{array}{l}\text { Yes. Furthermore, many cultural events are } \\
\text { directly organised by the "Famiglia di Maria" } \\
\text { Foundation, that is the most active on the } \\
\text { territory among the partners of the project }\end{array}$ \\
\hline & $\begin{array}{l}\text { Social mobilisation and } \\
\text { organisation (protests) }\end{array}$ & $\begin{array}{l}\text { Quantification of the number and duration of } \\
\text { protests the project and the number of } \\
\text { protesters that are from the local community }\end{array}$ & Quantitative & Negative & $0 \%$ for all of the partners \\
\hline \multirow{4}{*}{ Workers } & Child Labour & Percentage of labour that is child labour & Quantitative & Negative & $\begin{array}{l}\text { 0\% for all partners } \\
\text { There are activities within the project that are } \\
\text { paid only with reimbursement, but this is due }\end{array}$ \\
\hline & Unpaid Labour & Percentage of labour that is unpaid & Quantitative & Negative & $\begin{array}{l}\text { to the solidarity oriented nature of the project, } \\
\text { and the material work of installation of the } \\
\text { plant ("3eee" Company) has been }\end{array}$ \\
\hline & Paid labour-wages periodicity & $\begin{array}{l}\text { Are employees paid at known and } \\
\text { regular intervals? }\end{array}$ & $\begin{array}{l}\text { Semi-quantitative } \\
\quad \text { (Yes/No) }\end{array}$ & Yes & $\begin{array}{l}\text { Yes, for all the organisations involved in } \\
\text { the project. }\end{array}$ \\
\hline & Paid labour—wages deduction & $\begin{array}{l}\text { Are there deductions on employees' wages } \\
\text { that were enacted for reasons beyond an } \\
\text { employee's control? }\end{array}$ & $\begin{array}{l}\text { Semi-quantitative } \\
\text { (Yes/No) }\end{array}$ & No & $\begin{array}{l}\text { No, for all the organisations involved in } \\
\text { the project. }\end{array}$ \\
\hline
\end{tabular}


Table A1. Cont.

\begin{tabular}{|c|c|c|c|c|c|}
\hline Stakeholders Categories & Indicators Group & Indicators Subgroup-Questions & Indicators Type & $\begin{array}{c}\text { Desired } \\
\text { Direction/Answer }\end{array}$ & Results \\
\hline \multirow{11}{*}{$\begin{array}{l}\text { Workers } \\
\text { (Cont.) }\end{array}$} & $\begin{array}{l}\text { Wage gaps by sex, gender, } \\
\text { nationality, cultural group, and } \\
\text { race }\end{array}$ & $\begin{array}{l}\text { Quantification of wage gaps by sex, gender, } \\
\text { nationality, cultural group, and race }\end{array}$ & Quantitative & Negative & $\begin{array}{l}\text { Impossible to estimate due to the } \\
\text { different nature of the subjects } \\
\text { participating in the project: } \\
\text { employees do not belong to a } \\
\text { single company }\end{array}$ \\
\hline & $\begin{array}{c}\text { Paid labour-wages based on } \\
\text { living location }\end{array}$ & $\begin{array}{l}\text { Percentage of workers earning a living wage based on } \\
\text { their location }\end{array}$ & Quantitative & Positive & $\begin{array}{l}\text { Not relevant: no different location } \\
\text { connected to the project }\end{array}$ \\
\hline & Paid labour-minimum wage & $\begin{array}{c}\text { Percentage of workers earning the legal } \\
\text { minimum wage }\end{array}$ & Quantitative & Negative & $0 \%$ \\
\hline & Paid labour-health insurance & $\begin{array}{c}\text { Percentage of workers with benefits such as health } \\
\text { insurance }\end{array}$ & Quantitative & Positive & Not assessed \\
\hline & Safety-accidents and death & $\begin{array}{l}\text { Quantification of the number of workplace accidents } \\
\text { resulting in injuries or death over a period }\end{array}$ & Quantitative & Negative & None \\
\hline & Safety—education and training & $\begin{array}{c}\text { Are appropriate safety education and training } \\
\text { provided to employees? }\end{array}$ & $\begin{array}{l}\text { Semi-quantitative } \\
\text { (Yes/No) }\end{array}$ & Yes & Yes \\
\hline & $\begin{array}{l}\text { Safety—appropriate equipment } \\
\text { and availability }\end{array}$ & $\begin{array}{l}\text { Is the appropriate safety equipment for workers' } \\
\text { activities consistently available and accessible } \\
\text { to employees? }\end{array}$ & $\begin{array}{l}\text { Semi-quantitative } \\
\quad \text { (Yes/No) }\end{array}$ & Yes & Yes \\
\hline & Labour union—rights & Do workers have the right to unionise? & $\begin{array}{l}\text { Semi-quantitative } \\
\text { (Yes/No) }\end{array}$ & Yes & $\begin{array}{l}\text { Yes, but they do not, for the } \\
\text { following reasons: } \\
\text { In the "3eee" Company, because of } \\
\text { the very small dimensions of the } \\
\text { company; In the "Famiglia di Maria" } \\
\text { Foundation, in the "Con il Sud" } \\
\text { Foundation and in the Association } \\
\text { "Legambiente", because they are } \\
\text { solidarity oriented foundations and } \\
\text { an environmentalist association. }\end{array}$ \\
\hline & Labour union-affiliation & Are employees unionised? & $\begin{array}{l}\text { Semi-quantitative } \\
\text { (Yes/No) }\end{array}$ & Yes & No (see above) \\
\hline & Working hours & $\begin{array}{c}\text { Quantification of the average and maximum number } \\
\text { of hours worked per week by workers at } \\
\text { different levels }\end{array}$ & Quantitative & Negative & $\begin{array}{l}\text { Impossible to assess because of the } \\
\text { difference among partners. }\end{array}$ \\
\hline & $\begin{array}{l}\text { Paid leave-holidays and } \\
\text { vacations }\end{array}$ & $\begin{array}{l}\text { Quantification of the number of holidays and other } \\
\text { paid time off available to workers annually }\end{array}$ & Quantitative & Positive & $\begin{array}{l}\text { Impossible to assess because of the } \\
\text { difference among partners }\end{array}$ \\
\hline
\end{tabular}


Table A1. Cont.

\begin{tabular}{|c|c|c|c|c|c|}
\hline Stakeholders Categories & Indicators Group & Indicators Subgroup-Questions & Indicators Type & $\begin{array}{c}\text { Desired } \\
\text { Direction/Answer }\end{array}$ & Results \\
\hline \multirow[b]{4}{*}{$\begin{array}{l}\text { Workers } \\
\text { (Cont.) }\end{array}$} & Employment freedom and justice & \multirow{4}{*}{$\begin{array}{l}\text { Are workers free to end their employment } \\
\text { and not tied by debt to a company, lack of } \\
\text { mobility, monopoly of employment in the } \\
\text { region by the company, or the company } \\
\text { holding onto their legal documentation? } \\
\text { Is the technology used accessible and } \\
\text { affordable to developing countries? } \\
\text { Are research and development results } \\
\text { disseminated without barriers or } \\
\text { monetary charges? } \\
\text { Are the companies and actors involved } \\
\text { connected to violent conflicts, including war? } \\
\text { Have the companies and actors been sued or } \\
\text { fined for or known to be involved in } \\
\text { corruption and unethical practices? }\end{array}$} & $\begin{array}{l}\text { Semi-quantitative } \\
\text { (Yes/No) }\end{array}$ & Yes & Yes \\
\hline & Access to technology & & $\begin{array}{l}\text { Semi-quantitative } \\
\text { (Yes/No) }\end{array}$ & Yes & Yes \\
\hline & $\begin{array}{l}\text { Access to research and } \\
\text { development options }\end{array}$ & & $\begin{array}{l}\text { Semi-quantitative } \\
\text { (Yes/No) }\end{array}$ & Yes & Yes \\
\hline & $\begin{array}{l}\text { Corruption and unethical } \\
\text { practices }\end{array}$ & & $\begin{array}{l}\text { Semi-quantitative } \\
\text { (Yes/No) }\end{array}$ & No & No \\
\hline \multirow{4}{*}{ Society } & $\begin{array}{l}\text { Sustainability and social } \\
\text { responsibility—orientation }\end{array}$ & $\begin{array}{l}\text { Have the companies shown behaviour that } \\
\text { can be considered sustainability and social } \\
\text { responsibility oriented about the choice of } \\
\text { partners, suppliers, and relationships along } \\
\text { the supply chain? }\end{array}$ & $\begin{array}{l}\text { Semi-quantitative } \\
\text { (Yes/No) }\end{array}$ & Yes & Yes \\
\hline & $\begin{array}{l}\text { Sustainability and social } \\
\text { responsibility—behaviour }\end{array}$ & $\begin{array}{l}\text { Have the companies shown proactive } \\
\text { behaviour in terms of initiatives to promote } \\
\text { sustainability and social responsibility? }\end{array}$ & $\begin{array}{l}\text { Semi-quantitative } \\
\text { (Yes/No) }\end{array}$ & Yes & No \\
\hline & $\begin{array}{l}\text { Sustainability and social } \\
\text { responsibility-economic } \\
\text { contribution to regions } \\
\text { and nations }\end{array}$ & $\begin{array}{l}\text { To what extent has the activities along the life } \\
\text { cycle of the electrical energy system } \\
\text { contributed to economic progress for different } \\
\text { geographic regions or nations? }\end{array}$ & $\begin{array}{l}\text { Semi-quantitative } \\
\quad \text { (Scale } 1 \text { to } 5 \text { ) }\end{array}$ & Positive & $\begin{array}{l}3 \text { for the implementation territory; } \\
\text { Not assessed for other territories. }\end{array}$ \\
\hline & $\begin{array}{l}\text { Sustainability and environmental } \\
\text { responsibility-promotion }\end{array}$ & $\begin{array}{l}\text { Are the companies promoting low-carbon } \\
\text { energy systems over conventional fossil } \\
\text { energy systems at their respective stages in } \\
\text { the life cycle? }\end{array}$ & $\begin{array}{l}\text { Semi-quantitative } \\
\text { (Yes/No) }\end{array}$ & Yes & Yes \\
\hline
\end{tabular}




\section{References}

1. Plagg, B.; Piccoliori, G.; Oschmann, J.; Engl, A.; Eisendle, K. Primary Health Care and Hospital Management During COVID-19: Lessons from Lombardy. Risk Manag. Healthc. Policy 2021, 14, 3987-3992. [CrossRef] [PubMed]

2. Belleri, G.; Il Territorio Abbandonato. Covid, Politiche Regionali e Cure Primarie I Lombardia Sociale 2020, Program e Governance, Punti di Vista. Available online: http:/ / www.lombardiasociale.it/2020/04/24/il-territorio-abbandonato/?doing_wp_cron=1643 316844.5760290622711181640625 (accessed on 27 January 2022).

3. Bolognesi, M.; Magnaghi, A. Verso le comunità energetiche (in Italian: Towards energy communities). Sci. Del. Territ. 2020, 142-150. [CrossRef]

4. Rikkonen, P.; Tapio, P.; Rintamäki, H. Visions for small-scale renewable energy production on finnish farms-A Delphi study on the opportunities for new business. Energy Policy 2019, 129, 939-948. [CrossRef]

5. Lang, B.; Dolan, R.; Kemper, J.; Northey, G. Prosumers in times of crisis: Definition, archetypes and implications. J. Serv. Manag. 2020, 32, 176-189. [CrossRef]

6. Caramizaru, A.; Uihlein, A. Energy Communities: An Overview of Energy and Social Innovation; EUR 30083 EN; Publications Office of the European Union: Luxembourg, 2020. [CrossRef]

7. Sovacool, B.K.; Dworkin, M.H. Energy justice: Conceptual insights and practical applications. Appl. Energy 2015, 142, 435-444. [CrossRef]

8. European Union. Models of Local Energy Ownership and the Role of Local Energy Communities in Energy Transition in Europe. QG-01-18-933-EN-N; European Union: Brussels, Belgium, 2018. [CrossRef]

9. Burke, M.J.; Stephens, J.C. Political power and renewable energy futures: A critical review. Energy Res. Soc. Sci. 2018, 35, 78-93. [CrossRef]

10. Burchell, K.; Rettie, R.; Roberts, T. Community, the very idea!: Perspectives of participants in a demand-side community energy project. People Place Policy Online 2014, 8, 168-179. [CrossRef]

11. Yalçın-Riollet, M.; Garabuau-Moussaoui, I.; Szuba, M. Energy autonomy in Le Mené: A French case of grassroots innovation. Energy Policy 2014, 69, 347-355. [CrossRef]

12. Creamer, E.; Eadson, W.; van Veelen, B.; Pinker, A.; Tingey, M.; Braunholtz-Speight, T.; Markantoni, M.; Foden, M.; Lacey-Barnacle, M. Community energy: Entanglements of community, state, and private sector. Geogr. Compass 2018, 12 , e12378. [CrossRef]

13. Bomberg, E.; McEwen, N. Mobilizing community energy. Energy Policy 2012, 51, 435-444. [CrossRef]

14. Osti, G.; Pellizzoni, L. Energia e Innovazione tra Flussi Globali e Circuiti Locali (in Italian-Energy and Innovation Between Global Flows and Local Circuits); EUT Edizioni Università di Trieste: Trieste, Italy, 2018.

15. Bellamy, B.R.; Diamanti, J. Materialism and the Critique of Energy; MCM' Publishing: Chicago, IL, USA, 2018.

16. Andoni, M.; Robu, V.; Flynn, D.; Abram, S.; Geach, D.; Jenkins, D.; McCallen, P.; Peacock, A. Blockchain technology in the energy sector: A systematic review of challenges and opportunities. Renew Sustain. Energy Rev. 2019, 100, 143-174. [CrossRef]

17. European Commission. Directive (EU) 2018/2001 of the European parliament and of the council of 11 December 2018 on the promotion of the use of energy from renewable sources. Off. J. Eur. Union 2018, 328, 82-209.

18. European Commission. Directive (EU) 2019/944 of the European parliament and of the council of 5 June 2019 on common rules for the internal market for electricity and amending Directive. Off. J. Eur. Union 2019, 158, 125-199.

19. ENEA. La Comunità Energetica_Vademecum 2021 (in Italian: The Energy Community_Vademecum 2021); ENEA: Rome, Italy, 2021; Volume 24. [CrossRef]

20. Italian Government. Disposizioni Urgenti in Materia di Proroga di Termini Legislativi, di Organizzazione Delle Pubbliche Amministrazioni, Nonché di Innovazione Tecnologica D.L. 162/2019/A.C. 2325; Gazzetta Ufficiale della Repubblica Italiana: Rome, Italy, 2020. (In Italian)

21. Italian Government. LEGGE 28 febbraio 2020, n. 8. Conversione in Legge, con Modificazioni, del Decreto-Legge 30 Dicembre 2019, $n$. 162, Recante Disposizioni Urgenti in Materia di Proroga di Termini Legislativi, di Organizzazione delle Pubbliche Amministrazioni, Nonché di in; Gazzetta Ufficiale della Repubblica Italiana: Rome, Italy, 2020.

22. Caruso, V. Territorio e deindustrializzazione. Gli anni settanta e le origini del declino economico di Napoli est. Meridiana 2019, 96, 209-230.

23. Hoff, M.D.; Polack, R.J. Social dimensions of the environmental crisis: Challenges for social work. Soc. Work 1993, $38,204-211$.

24. Ministero della Giustizia. Profilo di Comunità Municipalità 6-Distretto 32 Barra—San Giovanni a Teduccio-Ponticelli 2010-2012; Ministero della Giustizia: Napoli, Italiy, 2012. (In Italian)

25. Freeman, R.E. A stakeholder theory of the modern corporation. In The Corporation And its Stakeholders; Clarkson, M., Ed.; University of Toronto Press: Toronto, ON, Canada, 2016; pp. 125-138. [CrossRef]

26. Freeman, R.E.; Harrison, J.S.; Wicks, A.C.; Parmar, B.L.; De Colle, S. Stakeholder Theory: The State of the Art; Cambridge University Press: New York, NY, USA, 2010.

27. Vassillo, C.; Restaino, D.; Santagata, R.; Viglia, S.; Vehmas, J.; Ulgiati, S. Barriers and solutions to the implementation of energy Efficiency. A survey about stakeholders' diversity, motivations and engagement in Naples (Italy). J. Environ. Account Manag. 2019, 7, 229-251. [CrossRef]

28. ISO, 14040. Environmental Management_Life Cycle Assessment_Principles and Framework; ISO: Geneva, Switzerland, 2006.

29. ISO, 14044. Life cycle Assessment_-Requirements and Guidelines; ISO: Geneva, Switzerland, 2006. 
30. UNEP. Guidelines for Social Life Cycle Assessment of Products and Organizations 2020; Benoît Norris, C., Traverso, M., Neugebauer, S., Ekener, E., Schaubroeck, T., Russo Garrido, S., Berger, M., Valdivia, S., Lehmann, A., Finkbeiner, M., et al., Eds.; United Nations Environment Programme (UNEP): Nairobi, Kenya, 2020.

31. Zamagni, A.; Feschet, P.; De Luca, A.I.; Iofrida, N.; Buttol, P. Social life cycle assessment. In Sustainability Assessment of RenewablesBased Products: Methods and Case Studies; John Wiley \& Sons, Ltd.: Chichester, UK, 2015; pp. 229-240. [CrossRef]

32. Fortier, M.O.P.; Teron, L.; Reames, T.G.; Munardy, D.T.; Sullivan, B.M. Introduction to evaluating energy justice across the life cycle: A social life cycle assessment approach. Appl. Energy 2019, 236, 211-219. [CrossRef]

33. Jørgensen, A.; Le Bocq, A.; Nazarkina, L.; Hauschild, M. Methodologies for social life cycle assessment. Int. J. Life Cycle Assess 2007, 13, 96. [CrossRef]

34. UNEP. The Methodological Sheets for Sub-Categories in Social Life Cycle Assessment (S-LCA); United Nations Environment Programme (UNEP): Nairobi, Kenya, 2013.

35. Alicea, R.J.B.; Fu, K. Social life-Cycle assessment (S-LCA) of residential rooftop solar panels using challenge-derived framework. Energy Sustain. Soc. 2022, 12, 7. [CrossRef]

36. Tsalidis, G.A. Integrating individual behavior dimension in social life cycle assessment in an energy transition context. Energies 2020, 13, 5984. [CrossRef]

37. Huijbregts, M.A.J.; Steinmann, Z.J.N.; Elshout, P.M.F.; Stam, G.; Verones, F.; Vieira, M.D.M.; Hollander, A.; Zijp, M.; val Zelm, R. ReCiPe 2016 v1.1. A Harmonized Life Cycle Impact Assessment Method at Midpoint and Endpoint Level Report I: Characterization; Rijksinstituut voor Volksgezondheid en Milieu RIVM: Bilthoven, The Netherlands, 2016.

38. EcoInvent v3.5. The EcoInvent Database n.d. Available online: https:/ /www.ecoinvent.org/database/database.html (accessed on 29 September 2020).

39. 3eee. Portifolio Page-PRIMA Comunità Energetica E Solidale D'italia (in Italian: First Energy and Solidarity Community in Italy 2021). 2021. Available online: https://www.3eee.it/portfolio_page/prima-comunita-energetica-e-solidale-ditalia/ (accessed on 15 June 2021).

40. ALEO SOLAR GMBH. Data Sheet-P23 320-330W 2020. Available online: https://www.aleo-solar.com/app/uploads/2016/01/ P23_320-330W_EN_web.pdf (accessed on 10 October 2021).

41. IEA. Snapshot of Global PV Markets 2014-Report IEA-PVPS T1-37: 2020; IEA: Paris, France, 2020.

42. Ansanelli, G.; Fiorentino, G.; Tammaro, M.; Zucaro, A. A life cycle assessment of a recovery process from end-of-life photovoltaic panels. Appl. Energy 2021, 290, 116727. [CrossRef]

43. Tagne, R.F.T.; Dong, X.; Anagho, S.G.; Ulgiati, S. Technologies, challenges and perspectives of biogas production in China and Africa. Energy Sustain. Dev. 2021, 23, 14799-14826. [CrossRef]

44. Muteri, V.; Cellura, M.; Curto, D.; Franzitta, V.; Longo, S.; Mistretta, M.; Parisi, M.L. Review on life cycle assessment of solar photovoltaic panels. Energies 2020, 13, 252. [CrossRef]

45. Bracquene, E.; Peeters, J.R.; Dewulf, W.; Duflou, J.R. Taking evolution into account in a parametric LCA model for PV panels. Procedia CIRP 2018, 69, 389-394. [CrossRef]

46. Oliveira, M.; Cocozza, A.; Zucaro, A.; Santagata, R.; Ulgiati, S. Circular economy in the agro-industry: Integrated environmental assessment of dairy products. Renew Sustain. Energy Rev. 2021, 148, 111314. [CrossRef]

47. Rossi, F.; Heleno, M.; Basosi, R.; Sinicropi, A. LCA driven solar compensation mechanism for renewable energy communities: The Italian case. Energy 2021, 235, 121374. [CrossRef] 